\title{
Maternal health service utilisation of adolescent women in sub-Saharan Africa: a systematic scoping review
}

\author{
Tensae Mekonnen ${ }^{1 *}$, Tinashe Dune ${ }^{1,2}$ and Janette Perz ${ }^{1}$
}

\begin{abstract}
Introduction: Sub-Saharan Africa has the highest rate of adolescent pregnancy in the world. While pregnancy during adolescence poses higher risks for the mother and the baby, the utilisation of maternity care to mitigate the effects is low. This review aimed to synthesise evidence on adolescent mothers' utilisation of maternity care in Sub-Saharan Africa and identify the key determinant factors that influence adolescent mothers' engagement with maternity care.

Method: A systematic review of scholarly literature involving seven databases: ProQuest, PubMed, EMBASE/Elsevier, SCOPUS, PsycINFO, CINAHL and Infomit was conducted. Studies published in English between 1990 and 2017 that examined Sub-Saharan adolescent mothers' experiences of utilising biomedical maternity care during pregnancy, delivery and the post-partum period were included.

Results: From 296 relevant articles 27 were identified that represent the experience of adolescent mothers' maternal health service utilisation in Sub-Saharan Africa. The review indicates that maternal health service utilisation in the majority of Sub-Saharan African countries is still low. There is also a wide discrepancy in the use of maternity care services by adolescent mothers across countries in Sub-Saharan Africa.

Conclusions: The review reveals that a significant number of adolescents in Sub-Saharan Africa do not access and use maternity services during pregnancy. Several factors from individual to systemic levels contributed to low access and utilisation. This implies that interventions targeting the women, their partners, healthcare professionals, communities and the organisations (local to national) are necessary to improve adolescent mother's engagement with maternity care in Sub-Saharan Africa.
\end{abstract}

Keywords: Adolescents, Teenage pregnancy, Maternal health care, Service utilisation, Sub-Saharan Africa, Antenatal care, Skilled birth delivery

\section{Background}

Adolescence is the transitional period from childhood to adulthood characterized by significant physiological, psychological and social changes [1]. Pregnancies that occur between the age of 10 and 19, in general, are referred to as an adolescent, or teenage pregnancy [2]. According to the World Health Organization (WHO), one in five adolescent girls worldwide give birth by the age of 18 and about 16 million girls aged between 15 to

\footnotetext{
* Correspondence: t.mekonnen@westernsydney.edu.au

${ }^{1}$ Translational Health Research Institute (THRI), School of Medicine, Western

Sydney University, Penrith, NSW 2751, Australia

Full list of author information is available at the end of the article
}

19 years give birth every year. The figures rise to one in three girls in the poorest regions such as Sub-Saharan Africa and South East Asia [3]. These figures are alarming as the majority of adolescent pregnancies in SubSaharan Africa are unintended. Evidence suggests that several factors that range from individual to societal levels expose adolescent women to the risk of unwanted pregnancy [4].

Past research suggests that adolescent pregnancy and childbearing are associated with higher health risks to the mother and her baby [5]. For example, Solomon and Isehak (1999) reported higher rates of preterm deliveries, prolonged labour and cephalic pelvic disproportion

(c) The Author(s). 2019 Open Access This article is distributed under the terms of the Creative Commons Attribution 4.0 International License (http://creativecommons.org/licenses/by/4.0/), which permits unrestricted use, distribution, and 
among teenage girls compared to older women [6]. Other researchers also showed that the risk of death during pregnancy and childbirth is higher among teenage mothers [2, 7]. In addition to the mother, adolescent pregnancy also poses a risk to the baby. Evidence suggests that babies born from adolescent mothers are more likely to have low birth weight [7] and Apgar score [8] and to be admitted to an intensive care unit [9]. Babies born in low - income countries from adolescent mothers also face $50 \%$ risk of stillbirth or dying before they are 1 month old in comparison to mothers whose age is above 20 [3]. These findings suggest that while reducing the rate of teenage pregnancies is ideal a concurrent goal is to support teenage mothers towards a safe and healthy pregnancy, delivery and baby through increased access and utilisation of skilled maternal health care [10].

The utilisation of mainstream maternal health services has a significant impact on the reduction of death and morbidity through early detection of danger signs and management of potential complications [11]. Maternal health care encompasses a range of services including antenatal care, skilled birth delivery care, and postnatal care. The provision of these services by formally trained and accredited health care professionals improves pregnancy outcomes significantly $[10,12]$. Research has demonstrated that when compared to women who did not receive skilled maternal health care those who did experience fewer complications and discomforts during pregnancy, underwent less invasive biomedical intervention during the birth and adjusted better to postnatal life and childrearing $[13,14]$.

Despite having these benefits, the utilisation of maternal health services by adolescent women is generally poor. For example, Magadi states that adolescent mothers in SubSaharan Africa receive inadequate ANC and have nonprofessional deliveries [15]. Another study suggests that only a quarter of adolescent women in Nigeria received safe delivery care $[11,15,16]$. The use of postnatal care (PNC) is also poor with only a third of adolescent mothers receiving the service in Sub-Saharan Africa [16]. Although there is a wide range of factors that influence maternal health care utilisation amongst teenage mothers in subSaharan Africa the evidence base is minimal. However, it is well established and reinforced by the Sustainable Development Goals that adverse outcomes for mothers, children, communities and countries are inevitable when women cannot utilise maternal health care services [17]. Even so, the majority of research in this area fails to engage theoretical frameworks or holistic models towards the development of strategies to encourage a systemic approach to the problem. In order to contribute to holistic recommendations, this systematic review uses the socioecological model to help improve maternal health care utilisation amongst teenage mothers in SubSaharan Africa.

Currently, there exists a number of systematic reviews that examine the utilisation of maternal health services by adolescents. Some of these have focused on only ANC [18] and others considered all women in developing counties [19] or synthesised country - specific evidence on the topic [20]. In Sub-Saharan Africa, although extensive research has been carried out on adolescent mothers' utilisation of maternity care during pregnancy, delivery and postnatal periods [15], no single study synthesised them to explore all aspects of adolescent mothers' healthcare-seeking behaviour. This systematic review, therefore, aims to fill this gap and make recommendations to policymakers, programme planners and clinicians, to improve the maternal health of adolescent women in Sub-Saharan Africa. This is significant to achieve the United Nation's (UN) target to reduce maternal mortality to less than 70 per 100,000 births under the Sustainable Development Goal 3 by 2030.

\section{Methods}

A rigorous systematic review was undertaken to locate studies that examined antenatal care, skilled birth delivery and PNC service utilisation of adolescent mothers in Sub-Saharan Africa.

\section{Search strategy}

Seven electronic databases were searched to identify potential articles that align with the review objective: ProQuest, PubMed, EMBASE/Elsevier, SCOPUS, PsycINFO, CINAHL and Infomit. Table 1 below presents the details of the search strategy including keyword combinations. A step-by-step search strategy was employed in this review. First, the first author identified relevant keywords by undertaking an initial MEDLINE search. The list and combinations of keywords were discussed, modified, and approved by the second author. A second search was then conducted across the identified databases and the results were downloaded and saved in an Endnote library for further screening and examination. Finally, studies conducted in Sub-Saharan Africa; involving quantitative, qualitative or mixed methods designs; focused on adolescents' utilisation of maternal health care; and written in English were included.

\section{Data synthesis and reporting}

A standard extraction template was used to capture data relevant to the review objective. Prevalence rates for ANC, skilled birth delivery and PNC were extracted from each study and grouped and analysed. Comparisons across countries and studies were then made. Factors that influence the use of maternal health care services were polled and analysed together through a 
Table 1 Summary of the inclusion/exclusion criteria and keywords

\begin{tabular}{|c|c|c|c|}
\hline Location & Sub-Saharan Africa & Out of Africa & Sub-Saharan Africa (Document text) \\
\hline Language & Written in English & Other languages & Select for English only \\
\hline Time & Any & None & N/A \\
\hline Population & Literature which include teenagers & $\begin{array}{l}\text { Literature which doesn't focus on } \\
\text { teenagers }\end{array}$ & $\begin{array}{l}\text { Teenagers (Abstract) or adolescent (Abstract) } \\
\text { or young age (Abstract) or youth (Abstract) }\end{array}$ \\
\hline $\begin{array}{l}\text { Phenomena/ } \\
\text { Target }\end{array}$ & $\begin{array}{l}\text { Studies concerned with maternal health } \\
\text { care utilisation by teenagers which includes; } \\
\text { ANC, Skilled birth delivery and postnatal care }\end{array}$ & $\begin{array}{l}\text { Not concerned with maternal health } \\
\text { care utilisation by teenagers which } \\
\text { includes ANC, skilled birth delivery and } \\
\text { postnatal care }\end{array}$ & $\begin{array}{l}\text { AND Antenatal (Title) OR ANC (Title) OR } \\
\text { Matern* (Title) OR Skilled birth delivery (Title) } \\
\text { OR Institutional delivery (Title) OR Skilled birth } \\
\text { OR PNC (Title) OR Pregnancy care (Title) OR } \\
\text { Prenatal care (Title) OR Pregnancy care }\end{array}$ \\
\hline $\begin{array}{l}\text { Study/ } \\
\text { literature } \\
\text { type }\end{array}$ & $\begin{array}{l}\text { Published primary research including } \\
\text { qualitative, quantitative and mixed method } \\
\text { designs }\end{array}$ & $\begin{array}{l}\text { Published literature which don't include } \\
\text { qualitative, quantitative and mixed } \\
\text { methods of data collection and analysis }\end{array}$ & N/A \\
\hline
\end{tabular}

socio-ecological lens to have a holistic understanding of the issue. Finally, a narrative synthesis and interpretation of the data was undertaken.

\section{Quality assessment}

The quality of the included studies that used quantitative data was performed using the International Society for Pharmacoeconomics and Outcomes Research (ISPOR) Good Research Practices for Retrospective Database Analysis Checklist. This tool has also been used in previous similar studies. The included studies were assessed across 17 criteria on a three-level scale. Items were awarded 0 if the "criterion was not met", 1 if the "criterion was partially met" and 2 "criterion was fully met." The maximum score was set at 34 (100\%). Studies with a cumulative score of $70 \%$ or more were classified as high quality, medium quality if the study scored from 50 to $70 \%$, and low quality if the study scored less than $50 \%$.

\section{Theoretical framework}

As noted, socioecological theory provides a useful framework for understanding the effects of multiple levels of influence (e.g., individual, family, peer/community and social system) on maternal health service utilisation [21]. According to the theory, use of maternal health care by an adolescent is influenced by a range of factors, such as individual experiences and attitudes, to the system level which is mainly related to policies and organizational level factors [22]. By providing a comprehensive view, socioecological theory helps program planners and providers identify the main social determinant factors and strategies to mitigate health problems [23].

\section{Results}

Search results

Of the 296 potentially relevant articles identified through a database search, 27 were included in this systematic review (see Fig. 1).

\section{Characteristics of included studies}

As demonstrated in Table 2, five studies were conducted in Kenya, three in South Africa, and Zimbabwe, Nigeria and Malawi each having two studies. Most studies (85\%) focused on the ANC experiences of women with 13 and 7 studies concentrated on skilled birth delivery and PNC services respectively. Twenty-one studies used quantitative methods, four used qualitative approaches and the remaining $(n=2)$ involved mixed-methods design. Most quantitative studies used bivariate and multivariate logistics regression analysis while qualitative studies involved thematic analysis. Three articles used theoretical approaches including the health belief model, Guba's model of trustworthiness, phenomenology and Donabedian's model. Most of the quantitative studies $(n=14)$ used data from the demographic and health surveys (DHS), which is retrospective, 8 of the reviews used primary data sources, and three were follow-up studies. Of the studies that used retrospective data one study used 3 years of data to minimize recall bias.

\section{Study quality}

As shown in Table 3, the quality assessment tool evaluated the included studies based on the following four major components: a) objectives, b) methods, c) results, and d) discussion. A total of 17 specific quality assessment sub-criteria where weighted according to a modified version of the International Society for Pharmacoeconomics and Outcomes Research (ISPOR) Good Research Practices for Retrospective Database. The checklist sub-criteria provided an overall indication of a study's quality level as strong (score $=2$ ), moderate $($ score $=1)$ and weak $($ score $=0)$. Study quality varied significantly across the studies. Overall, 11 studies were identified as high quality (score $\geq 70 \%$ ), eight were of moderate quality (score between 50 and $69 \%$ ), and the remaining three papers were poor in quality (score $<50 \%$ ). 


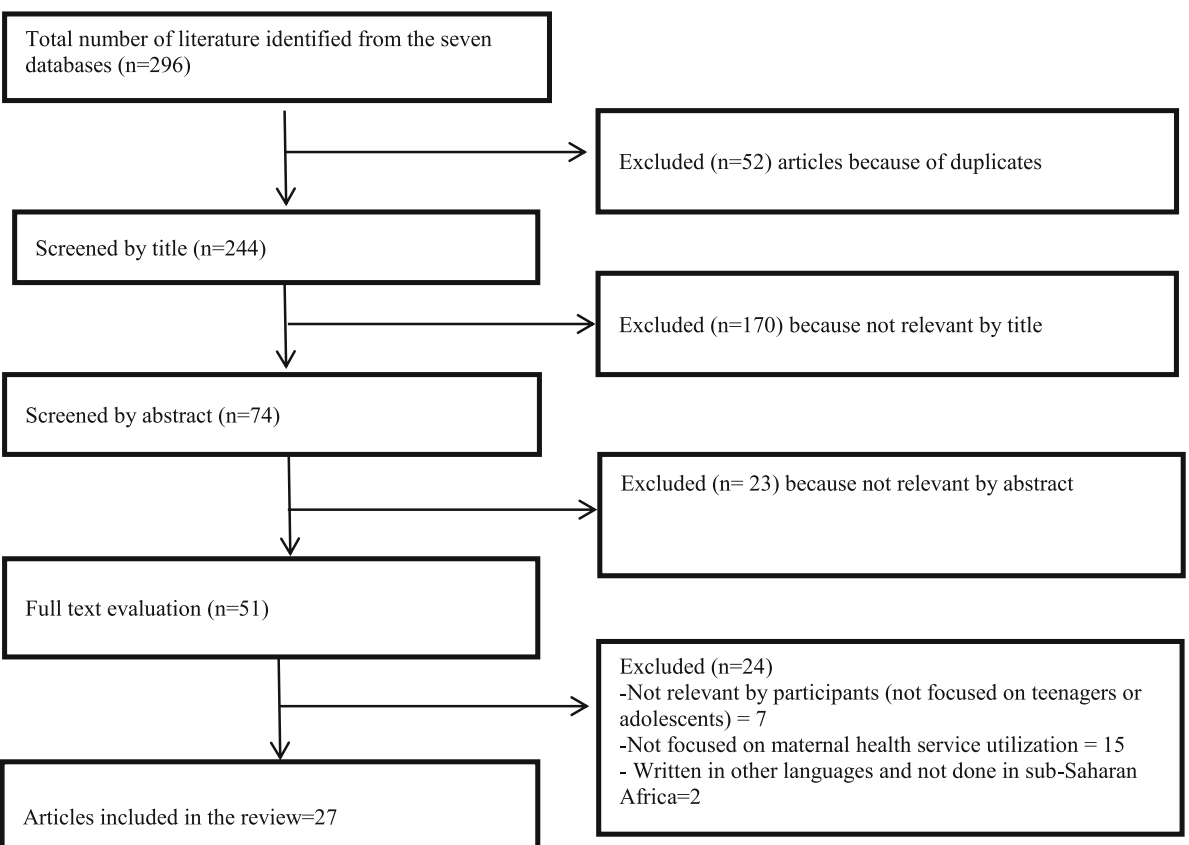

Fig. 1 Article Selection Process

\section{Major findings}

Following the analysis of the extracted data from individual studies the synthesised results regarding the utilisation and socioecological factors related to maternal health care services are presented in four categories: Antenatal Care Utilisation, Skilled Birth Delivery Utilisation, Postnatal Care Utilisation and Factors Influencing Maternal Health Care Utilisation.

\section{ANC utilisation}

Twenty-two out of 27 studies reported on adolescent women's engagement with ANC services. Figures 2 and 3 below summarise the proportion of adolescent women who had accessed ANC at least once and those who accessed ANC four or more times during pregnancy. This proportion ranges from $29 \%$ in Ethiopia to $93 \%$ in South Africa and Kenya for at least one ANC visit, and from $30 \%$ in Ethiopia to 93.7\% in Malawi 4+ visits.

Five studies also reported on the timing of ANC visits with the majority saying late attendance to ANC (late second trimester and after that) care by adolescent women [15, 25, 30, 35]. However, Musarandega and colleagues said that adolescent women were more likely to present for $\mathrm{ANC}$ in the first trimester compared to older women [34]. Being a first-time adolescent mother was also said to have a positive association with first trimester ANC visits [30].

\section{Skilled birth delivery utilisation}

Thirteen out of twenty-seven studies described the use of skilled birth delivery services by adolescent mothers during the birth of their babies. Figure 4 below shows the proportion of adolescent mothers who received skilled care during delivery. This proportion ranges from $10 \%$ in Ethiopia to $72 \%$ in Guinea.

\section{PNC utilisation}

Only seven studies out of 27 described PNC. One study reported that adolescent mothers were more likely to have babies with low Apgar scores and low birthweight compared to older mothers [37]. Finally, one study indicated that adolescents do not receive optimal maternity care, and are not followed up adequately immediately after delivery [32]. Figure 5 below indicates the use of PNC service by adolescent mothers in sub-Saharan Africa.

\section{Factors affecting maternal health care utilisation}

Twenty-two out of 27 studies reported on the factors affecting adolescent women's utilisation of maternal health care services in Sub-Saharan Africa. Figure 6 below provides a socioecological summary of these factors across four levels.

\section{Individual level}

At the individual level, factors such as educational status, age, residence, economic status and knowledge and 
Table 2 Characteristics of included studies

\begin{tabular}{|c|c|c|c|c|c|c|c|c|}
\hline No & $\begin{array}{l}\text { Authors/ } \\
\text { Year }\end{array}$ & $\begin{array}{l}\text { Country of } \\
\text { study }\end{array}$ & Sample size & Type of care & Outcome measured & $\begin{array}{l}\text { Study } \\
\text { design/data } \\
\text { collection } \\
\text { method }\end{array}$ & Data Analysis & $\begin{array}{l}\text { Theoretical } \\
\text { Approach }\end{array}$ \\
\hline 1 & [24] & Ethiopia & $\begin{array}{l}994 \text { women aged } \\
\text { between } 14 \text { and } 19\end{array}$ & ANC & $\begin{array}{l}\text { Factors influencing the } \\
\text { utilisation of ANC }\end{array}$ & $\begin{array}{l}\text { Survey/ } \\
\text { Quantitative }\end{array}$ & $\begin{array}{l}\text { Bivariate and } \\
\text { multivariate } \\
\text { analyses }\end{array}$ & $\mathrm{N} / \mathrm{A}$ \\
\hline 2 & [25] & Kenya & $\begin{array}{l}1675 \text { women aged } \\
15-24\end{array}$ & ANC & $\begin{array}{l}\text { Relationship between } \\
\text { timing of first (ANC) visit } \\
\text { and type of delivery } \\
\text { assistance }\end{array}$ & $\begin{array}{l}\text { Survey/ } \\
\text { Quantitative }\end{array}$ & $\begin{array}{l}\text { Multivariate } \\
\text { logistic regression }\end{array}$ & $\mathrm{N} / \mathrm{A}$ \\
\hline 3 & [16] & Nigeria & $\begin{array}{l}2434 \text { married } \\
\text { adolescents aged } \\
15-19\end{array}$ & $\begin{array}{l}\text { ANC, Delivery } \\
\text { and PNC }\end{array}$ & $\begin{array}{l}\text { Factors associated with } \\
\text { maternity services }\end{array}$ & $\begin{array}{l}\text { Survey/ } \\
\text { Quantitative }\end{array}$ & $\begin{array}{l}\text { Pearson chi- } \\
\text { square test and } \\
\text { binary logistic } \\
\text { regression }\end{array}$ & $\mathrm{N} / \mathrm{A}$ \\
\hline 4 & [26] & Mali & $\begin{array}{l}1646 \text { adolescent } \\
\text { mothers age } 15-19\end{array}$ & $\begin{array}{l}\text { ANC, Delivery } \\
\text { and PNC }\end{array}$ & $\begin{array}{l}\text { Factors associated with the } \\
\text { utilisation of maternal } \\
\text { services }\end{array}$ & $\begin{array}{l}\text { Survey/ } \\
\text { Quantitative }\end{array}$ & $\begin{array}{l}\text { Bivariate and } \\
\text { multivariate } \\
\text { analyses }\end{array}$ & N/A \\
\hline 5 & {$[27]$} & Zimbabwe & $\begin{array}{l}80 \text { adolescent } \\
\text { mothers aged } 19 \text { or } \\
\text { younger }\end{array}$ & ANC & $\begin{array}{l}\text { Factors influencing } \\
\text { adolescents' non-utilisation } \\
\text { of ANC services }\end{array}$ & Quantitative & $\begin{array}{l}\text { Descriptive } \\
\text { (Frequency and } \\
\text { proportion }\end{array}$ & $\begin{array}{l}\text { Health belief } \\
\text { model }\end{array}$ \\
\hline 6 & [28] & Niger & $\begin{array}{l}934 \text { adolescent } \\
\text { mothers aged 15-19 }\end{array}$ & $\begin{array}{l}\text { ANC, Safe } \\
\text { delivery and } \\
\text { Immunization }\end{array}$ & $\begin{array}{l}\text { Potential factors associated } \\
\text { with the utilisation of } \mathrm{MCH} \\
\text { care services }\end{array}$ & $\begin{array}{l}\text { Survey/ } \\
\text { Quantitative }\end{array}$ & $\begin{array}{l}\text { Multivariate } \\
\text { logistic regression } \\
\text { models }\end{array}$ & N/A \\
\hline 7 & [29] & Malawi & $\begin{array}{l}615 \text { adolescents } \\
\text { aged } 10-19 \text { years }\end{array}$ & ANC & $\begin{array}{l}\text { Why antenatal care (ANC) } \\
\text { programs for adolescents } \\
\text { may need to be improved? }\end{array}$ & Quantitative & $\begin{array}{l}\text { Chi-square test } \\
\text { and binary } \\
\text { logistic regression }\end{array}$ & $\mathrm{N} / \mathrm{A}$ \\
\hline 8 & {$[30]$} & Tanzania & $N=440$ & ANC & $\begin{array}{l}\text { Factors influencing early } \\
\text { and late ANC attendance }\end{array}$ & Quantitative & $\begin{array}{l}\text { logistic regression } \\
\text { models }\end{array}$ & N/A \\
\hline 9 & [31] & $\begin{array}{l}\text { Sub- } \\
\text { Saharan } \\
\text { Africa }\end{array}$ & $\begin{array}{l}\text { Data from } 20 \\
\text { countries (total of 74, } \\
559 \text { births) }\end{array}$ & Safe delivery & $\begin{array}{l}\text { Perceived size of newborn } \\
\text { and caesarean section } \\
\text { deliveries among } \\
\text { teenagers }\end{array}$ & $\begin{array}{l}\text { Quantitative } \\
\text { and } \\
\text { comparative } \\
\text { study }\end{array}$ & $\begin{array}{l}\text { Multiple logistic } \\
\text { regression models }\end{array}$ & N/A \\
\hline 10 & {$[32]$} & Swaziland & $\begin{array}{l}N=33 \text { pregnant } \\
\text { adolescent mothers }\end{array}$ & $\begin{array}{l}\text { Safe delivery } \\
\text { and PNC }\end{array}$ & Quality of maternity care & $\begin{array}{l}\text { Quantitative } \\
\text { and } \\
\text { qualitative }\end{array}$ & Content analysis & $\begin{array}{l}\text { Donabedian's } \\
\text { (1988) model }\end{array}$ \\
\hline 11 & [33] & South Africa & $\begin{array}{l}N=20 \text { aged } 12- \\
19 \text { years }\end{array}$ & ANC & Communication in ANC & Qualitative & $\begin{array}{l}\text { Tesch's method } \\
\text { of data analysis } \\
\text { (Creswell, 2008: } \\
\text { 186) }\end{array}$ & $\mathrm{N} / \mathrm{A}$ \\
\hline 12 & [34] & Zimbabwe & $N=40$ & $\begin{array}{l}\text { ANC and } \\
\text { PMTCT }\end{array}$ & Gaps in service uptake & $\begin{array}{l}\text { Quantitative } \\
\text { and } \\
\text { retrospective } \\
\text { analysis }\end{array}$ & $\begin{array}{l}\text { Multivariable } \\
\text { binomial } \\
\text { regression } \\
\text { analysis }\end{array}$ & N/A \\
\hline 13 & {$[35]$} & Nigeria & $N=114$ & $\begin{array}{l}\text { ANC, safe } \\
\text { delivery and } \\
\text { PNC }\end{array}$ & $\begin{array}{l}\text { Prevalence of pregnancy } \\
\text { Complications and } \\
\text { interventions }\end{array}$ & Quantitative & Fisher's exact test & N/A \\
\hline 14 & {$[36]$} & Kenya & $\begin{array}{l}898 \text { female } \\
\text { adolescents between } \\
15 \text { and } 19 \text { years }\end{array}$ & $\begin{array}{l}\text { ANC, skilled } \\
\text { birth } \\
\text { attendance } \\
\text { and PNC }\end{array}$ & $\begin{array}{l}\text { Factors that impact } \\
\text { maternity care utilisation }\end{array}$ & $\begin{array}{l}\text { Survey/ } \\
\text { Quantitative }\end{array}$ & $\begin{array}{l}\text { Bivariate and } \\
\text { multivariate } \\
\text { analyses }\end{array}$ & $\mathrm{N} / \mathrm{A}$ \\
\hline 15 & {$[37]$} & Sudan & 459 & $\begin{array}{l}\text { ANC and safe } \\
\text { delivery }\end{array}$ & $\begin{array}{l}\text { Risk of anaemia, operative } \\
\text { delivery, and perinatal } \\
\text { complications }\end{array}$ & Quantitative & $\begin{array}{l}\text { Chi-square test } \\
\text { and Fisher's exact } \\
\text { test }\end{array}$ & N/A \\
\hline 16 & [38] & Kenya & $\begin{array}{l}278 \text { adolescent } \\
\text { mothers aged } 19 \\
\text { and younger }\end{array}$ & ANC & $\begin{array}{l}\text { Factors affecting utilisation } \\
\text { of ANC }\end{array}$ & $\begin{array}{l}\text { Survey/ } \\
\text { Quantitative }\end{array}$ & $\begin{array}{l}\text { Bivariate and } \\
\text { multivariate } \\
\text { analyses }\end{array}$ & N/A \\
\hline 17 & [39] & South Africa & 383 & ANC & $\begin{array}{l}\text { Factors that influence ANC } \\
\text { uptake }\end{array}$ & $\begin{array}{l}\text { Quantitative } \\
\text { and } \\
\text { qualitative }\end{array}$ & $\begin{array}{l}\text { Bivariate and } \\
\text { multivariate } \\
\text { analyses }\end{array}$ & N/A \\
\hline
\end{tabular}


Table 2 Characteristics of included studies (Continued)

\begin{tabular}{|c|c|c|c|c|c|c|c|c|}
\hline No & $\begin{array}{l}\text { Authors/ } \\
\text { Year }\end{array}$ & $\begin{array}{l}\text { Country of } \\
\text { study }\end{array}$ & Sample size & Type of care & Outcome measured & $\begin{array}{l}\text { Study } \\
\text { design/data } \\
\text { collection } \\
\text { method }\end{array}$ & Data Analysis & $\begin{array}{l}\text { Theoretical } \\
\text { Approach }\end{array}$ \\
\hline 18 & [40] & Malawi & $\begin{array}{l}2160 \text { adolescent } \\
\text { married women } \\
\text { aged } 15-19\end{array}$ & ANC and PNC & $\begin{array}{l}\text { Factors that influence ANC } \\
\text { and PNC }\end{array}$ & $\begin{array}{l}\text { Survey/ } \\
\text { Quantitative }\end{array}$ & $\begin{array}{l}\text { Bivariate and } \\
\text { multivariate } \\
\text { analyses }\end{array}$ & N/A \\
\hline 19 & [15] & $\begin{array}{l}\text { Sub- } \\
\text { Saharan } \\
\text { Africa }\end{array}$ & $\begin{array}{l}\text { Data from } 21 \text { DHS } \\
\text { countries were } \\
\text { pooled }\end{array}$ & $\begin{array}{l}\text { ANC and } \\
\text { Delivery }\end{array}$ & $\begin{array}{l}\text { Association between } \\
\text { maternal age ANC and } \\
\text { delivery care }\end{array}$ & $\begin{array}{l}\text { Survey/ } \\
\text { Quantitative }\end{array}$ & $\begin{array}{l}\text { Bivariate and } \\
\text { multivariate } \\
\text { analyses }\end{array}$ & N/A \\
\hline 20 & [41] & Tanzania & $\begin{array}{l}\text { Adolescents aged } \\
15-20 \text { years }\end{array}$ & $\begin{array}{l}\text { ANC and RH } \\
\text { service }\end{array}$ & Barriers to SRH care & $\begin{array}{l}\text { Qualitative/ } \\
\text { focus group }\end{array}$ & Thematic analysis & Phenomenology \\
\hline 21 & [42] & Kenya & $\begin{array}{l}393 \text { adolescents } \\
\text { aged } 15-19\end{array}$ & $\begin{array}{l}\text { ANC, skilled } \\
\text { birth } \\
\text { attendance } \\
\text { and PNC }\end{array}$ & $\begin{array}{l}\text { Factors that influence ANC } \\
\text { and PNC. }\end{array}$ & Quantitative & $\begin{array}{l}\text { Multilevel logit } \\
\text { models }\end{array}$ & N/A \\
\hline 22 & [43] & Uganda & $\begin{array}{l}N=18 \text { key } \\
\text { informants (health } \\
\text { workers and } \\
\text { community leaders) }\end{array}$ & ANC & $\begin{array}{l}\text { Factors affecting utilisation } \\
\text { of teenager friendly ANC }\end{array}$ & Qualitative & Thematic analysis & N/A \\
\hline 23 & [11] & $\begin{array}{l}\text { Developing } \\
\text { countries }\end{array}$ & & $\begin{array}{l}\text { ANC, safe } \\
\text { delivery and } \\
\text { immunisation. }\end{array}$ & $\begin{array}{l}\text { Utilisation of ANC, delivery } \\
\text { and PNC }\end{array}$ & $\begin{array}{l}\text { Survey/ } \\
\text { Quantitative }\end{array}$ & $\begin{array}{l}\text { Bivariate and } \\
\text { multivariate } \\
\text { logistic regression }\end{array}$ & N/A \\
\hline 24 & [44] & Kenya & $\begin{array}{l}301 \text { adolescent } \\
\text { mothers aged 15-19 } \\
\text { years }\end{array}$ & $\begin{array}{l}\text { ANC, safe } \\
\text { delivery and } \\
\text { PNC }\end{array}$ & Maternity care utilisation & $\begin{array}{l}\text { Survey/ } \\
\text { Quantitative }\end{array}$ & $\begin{array}{l}\text { Bivariate and } \\
\text { multivariate } \\
\text { analyses }\end{array}$ & N/A \\
\hline 25 & [45] & $\begin{array}{l}\text { Central and } \\
\text { west Africa }\end{array}$ & $\begin{array}{l}\text { Adults aged } 20-49 \\
\text { and Adolescent aged } \\
10-19\end{array}$ & ANC & HIV testing in ANC & $\begin{array}{l}\text { Survey/ } \\
\text { Quantitative }\end{array}$ & $\begin{array}{l}\text { Bivariate and } \\
\text { multivariate } \\
\text { analyses }\end{array}$ & N/A \\
\hline 26 & {$[46]$} & South Africa & $\begin{array}{l}18 \text { adolescent,15-19 } \\
\text { yrs }\end{array}$ & ANC and PNC & Maternity care perception & Qualitative & & $\begin{array}{l}\text { Grounded } \\
\text { theory }\end{array}$ \\
\hline 27 & [47] & Kenya & 13-19 years & ANC & $\begin{array}{l}\text { Factors influencing } \\
\text { utilisation of antenatal care } \\
\text { service among teenagers }\end{array}$ & $\begin{array}{l}\text { Survey/ } \\
\text { Quantitative }\end{array}$ & $\begin{array}{l}\text { chi square test } \\
\text { and logistic } \\
\text { regression }\end{array}$ & N/A \\
\hline
\end{tabular}

perceived need of maternal health care were identified to influence the utilisation of maternity care by adolescent mothers in Sub-Saharan Africa. The majority of studies included in this review reported that women's education is the most significant predictor for the utilisation of maternal health services with women having a secondary and above level of education more likely to seek maternity care than those who had no education $[16,25,28,29,36,40,44]$. Alemayehu and colleagues explain that education helps women develop greater confidence to make decisions regarding their health [24]. Furthermore, seven studies reported that adolescent women who were residing in urban areas were more likely to access maternal health care than those living in rural areas $[25,36,40,48]$. Some studies further explained the urban-rural discrepancy. According to the reviewed studies the reason for rural-urban disparity in utilisation of health services can be explained by variations in access to maternal health resources, where urban location often tend to be more advantaged relative to rural areas [36] and rural women influenced by attitude, belief and social norms that discourage to use maternal health care [24-26, 42].

Furthermore, some studies identified that although adolescent women knew the benefits of having ANC and delivering with the assistance of a skilled provider, they did not attend ANC care and received skilled birth delivery due to fear of disclosing pregnancy and lack of money for ANC registration [27]. Similarly, adolescent women who have had more than three children with less than 2 years between pregnancies were less likely to utilize postnatal services compared to adolescent women with fewer children and or more spacing [40]. Other factors that were found to be positively associated to the use of maternal health service among adolescent mothers include mass media exposure [36, 40, 44], low parity $[25,38]$ and employment status [38].

\section{Interpersonal or family level factors}

The review also identified interpersonal level factors that influence adolescent women's utilisation of maternal health care which includes family traditions, husband's 


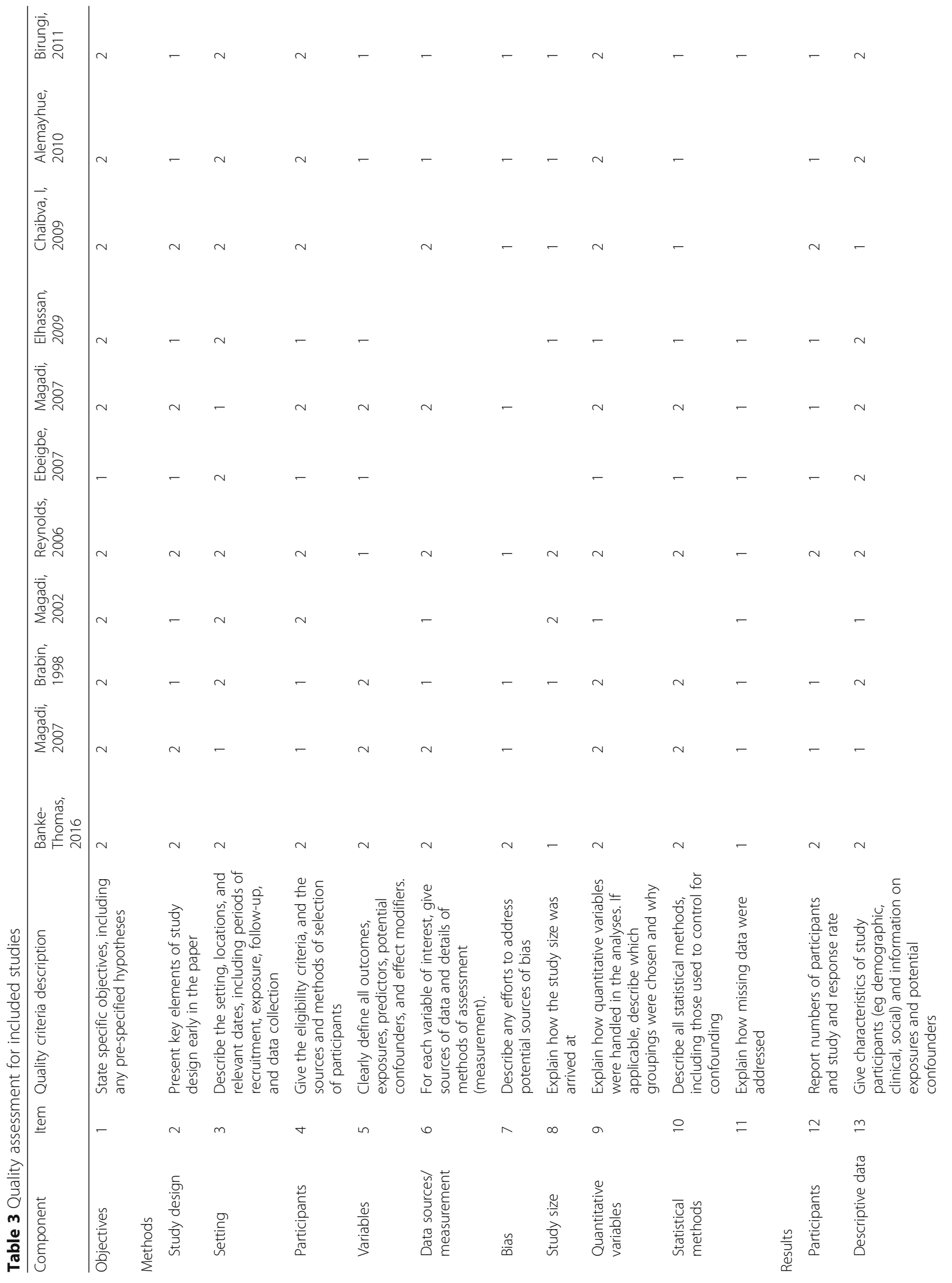




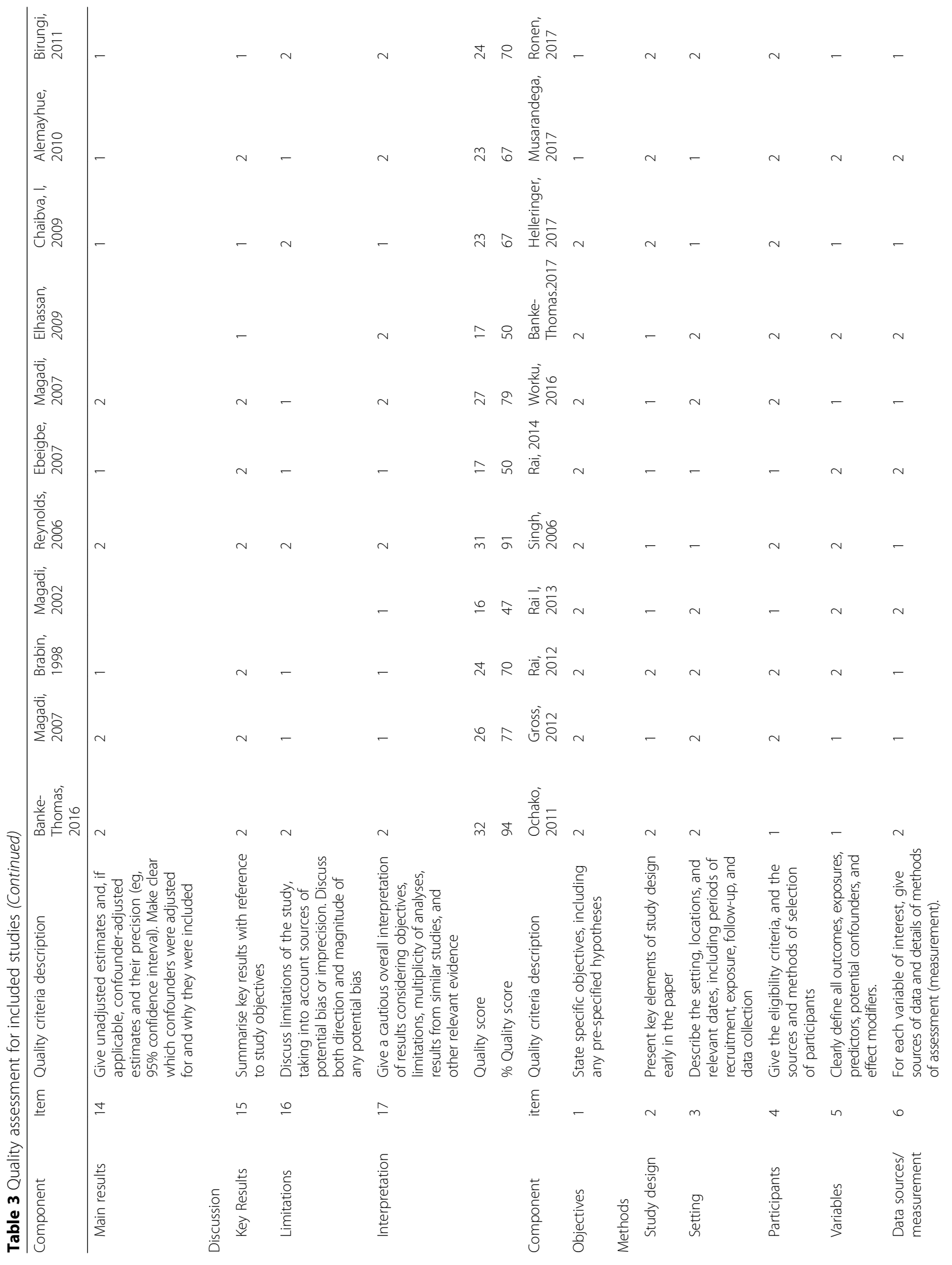




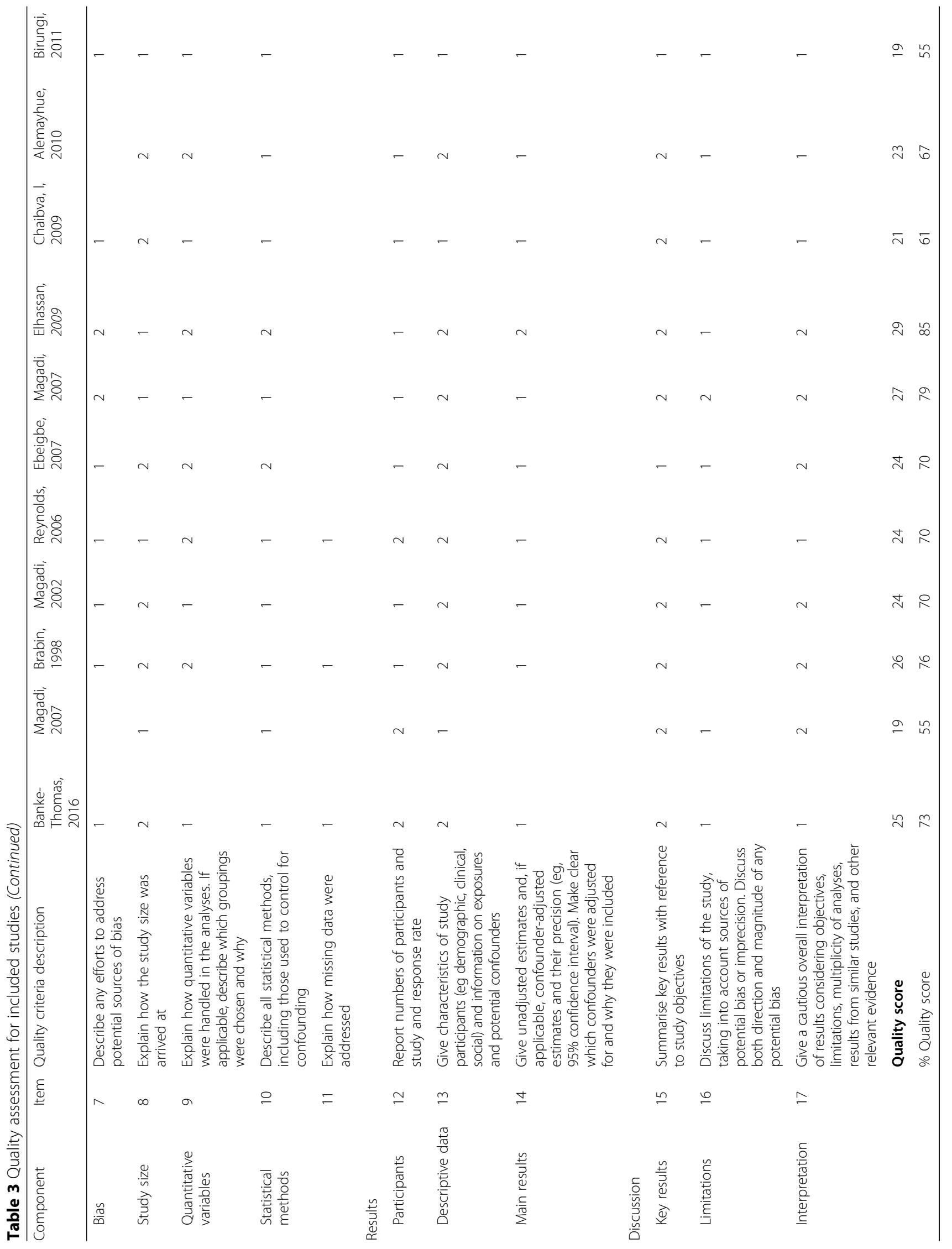




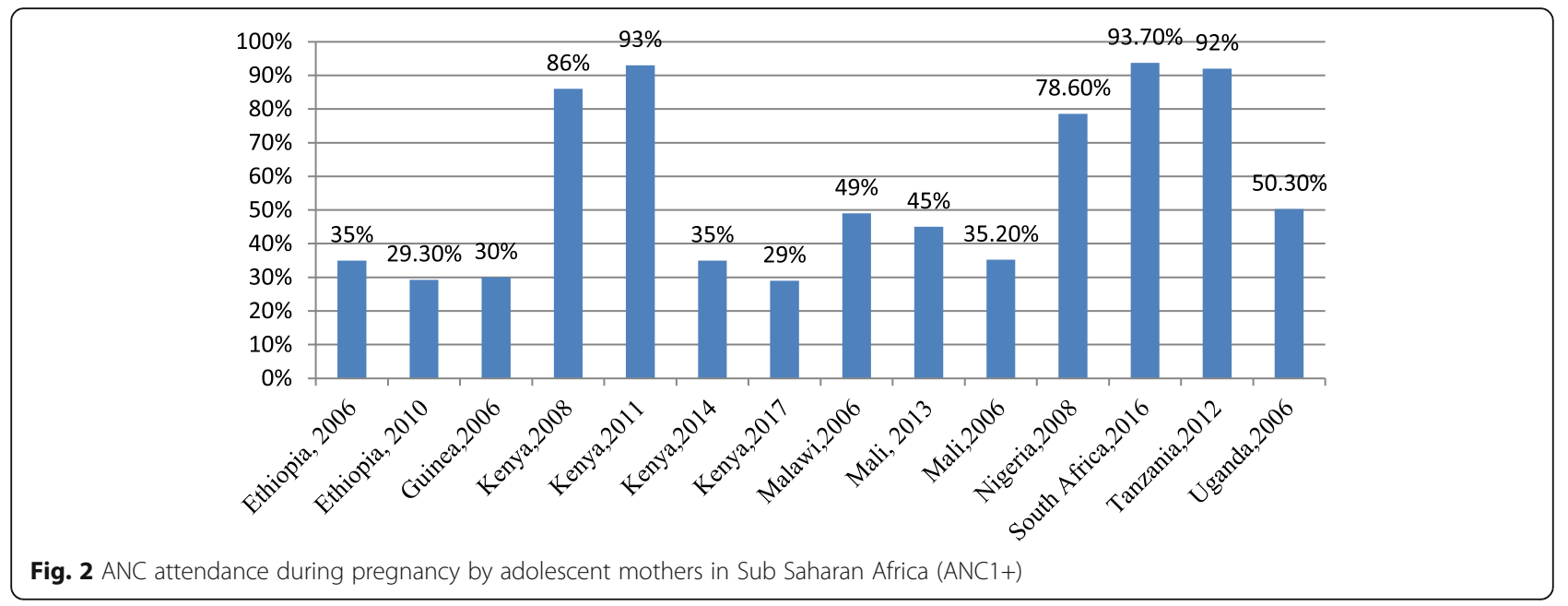

knowledge, education and perceptions, peer influence and the influence of other family members. Some studies that captured health provider perspectives reported that adolescent mothers often experienced unintended pregnancy which further complicated their maternal health seeking behaviour and journeys. In such situations, teenage mothers frequently experienced rejection from their partner and social isolation [41]. Following these outcomes, the more fortunate teenage mothers were allowed to stay with their parents albeit with limited emotional, financial and social support [30]. Other young mothers may not be disowned, asked to leave and/or forcibly removed from their home and community [41]. These difficulties are the result of negative sociocultural perceptions of unplanned teenage pregnancy often reinforced by religious, traditional and or spiritual beliefs held within families and communities [41]. Also, Rai and Singh suggest that the chances of accessing maternity care were lower among those teenage mothers who reported the birth as unwanted [40]. These factors imply that teenage mothers may not able to access and utilise available reproductive health care services at any point during their pregnancy [43]. However, those adolescent mothers who were married [25] and had educated husbands [40] were significantly likely to use maternal health services.

Adolescent women's interaction with health providers had both positive and negative effects on their experience of accessing maternity care. In some studies, health providers were described to be "harsh," "judgmental" and "not trustworthy" with regards to confidentiality. This discouraged adolescent women

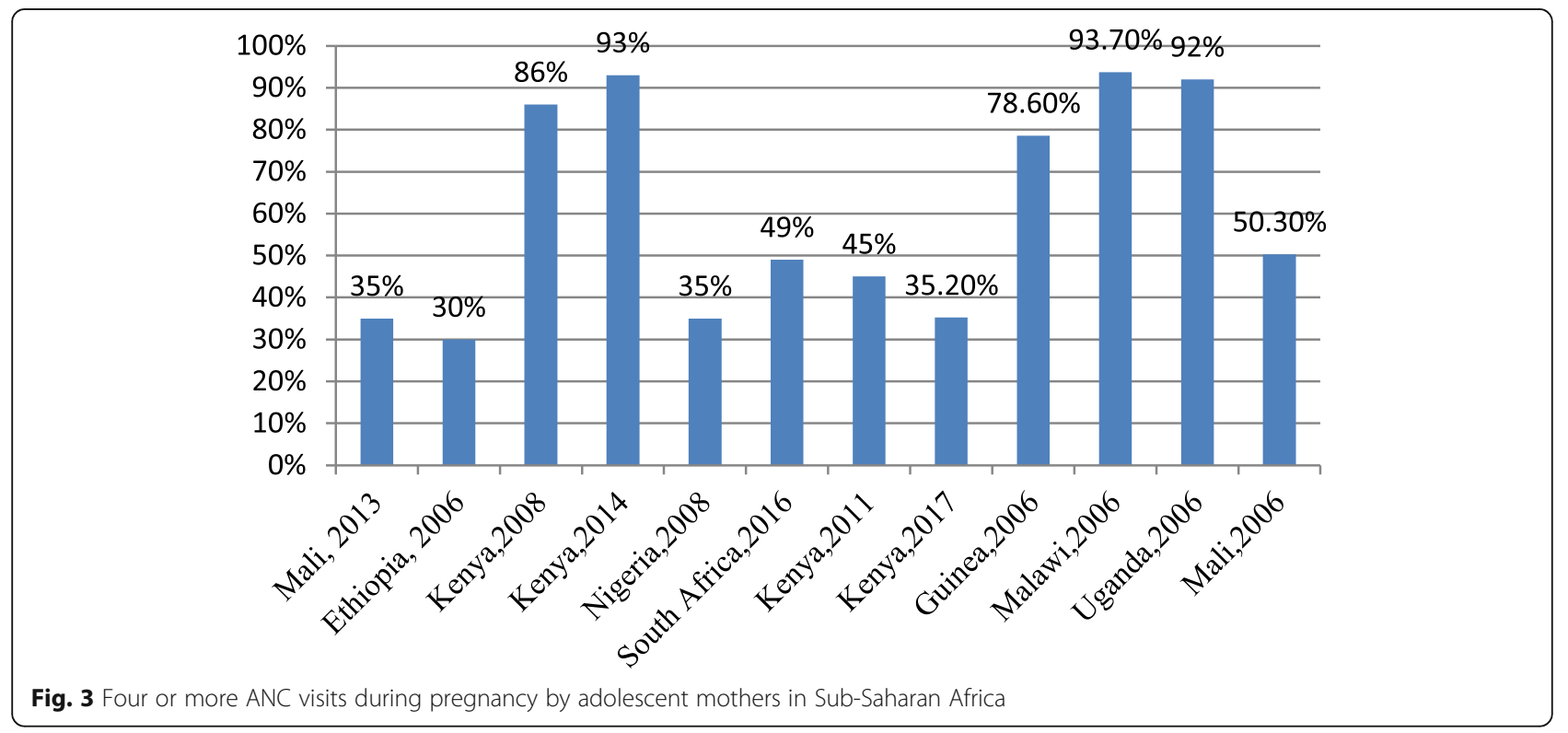




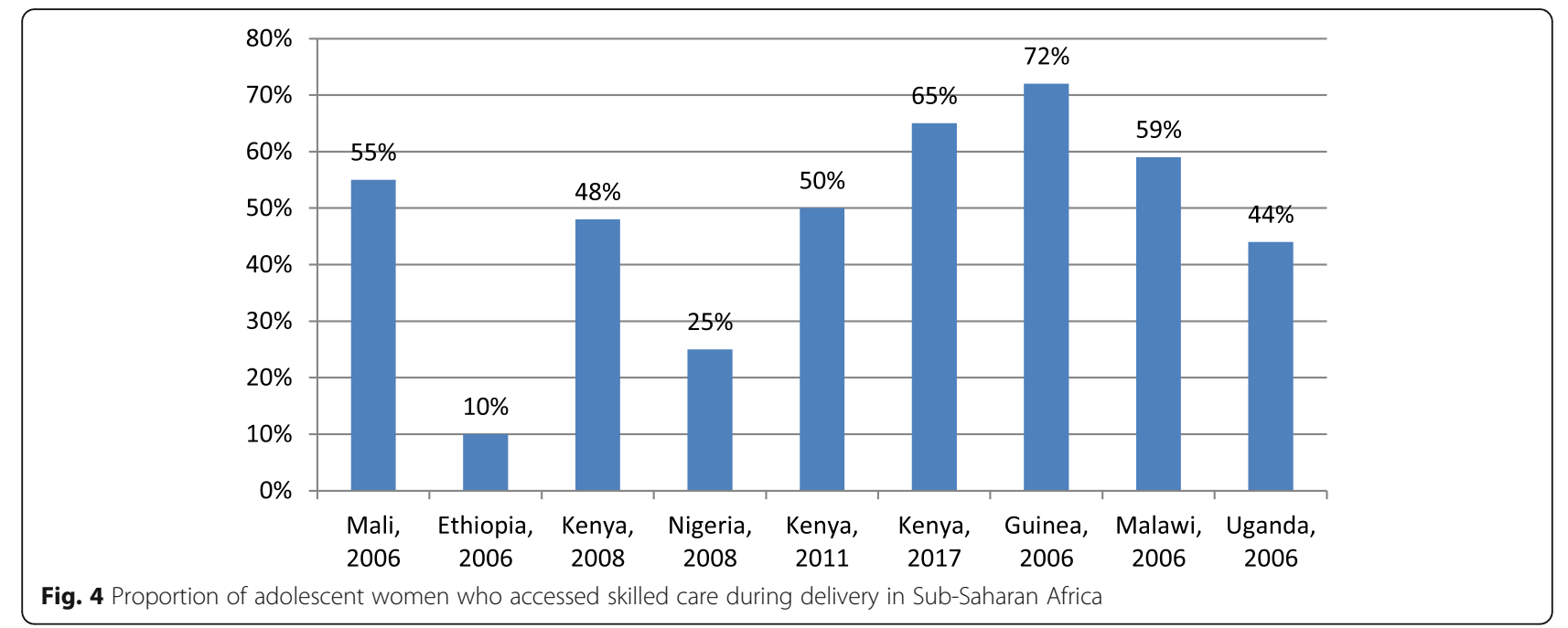

from accessing maternity care [41, 49]. Health providers also reported a lack of training and supervision related to adolescent sexual and reproductive health services [50] which made it challenging to provide adolescent - friendly reproductive health services. In some instances, HCPs were reluctant to provide reproductive health care due to lack of clarity in legislation and fear of condoning adolescent sexual activity [49].

\section{Organizational level}

The review also identifies several organisational level factors that positively or negatively influence adolescent mothers' utilisation of maternity care in Sub-Saharan Africa. Although HCPs view teenage mothers as a special group that requires great attention, the lack of teenage friendly services constrained their utilisation of ANC care, with adolescent women attending adult oriented ANC services that do not provide adequate privacy, time or specific training in teenage pregnancy to HCPs [41, 43]. Due to a lack of trust for health providers, pregnant teenage mothers were also reported to experience communication barriers with health providers when accessing ANC care [33]. Others reported a severe shortage of HCPs leading to long waiting times for pregnant adolescent women in ANC services and poor satisfaction with the service $[39,43,46]$. Distance from the health facility [39] was also reported to constrain adolescent mothers engagement with maternity care. Although several adolescent mothers represented in the studies felt the need for information to prepare themselves for pregnancy and motherhood responsibilities better; many did not receive this education due to the lack of services and resources [46]. HCPs also corroborated the adolescent women's claims that they had a shortage of guidelines and educational materials to provide maternal health education to adolescent mothers [50].

Four additional studies identified an association between ANC and skilled birth delivery care. While Ochako and colleagues [25] reported the positive

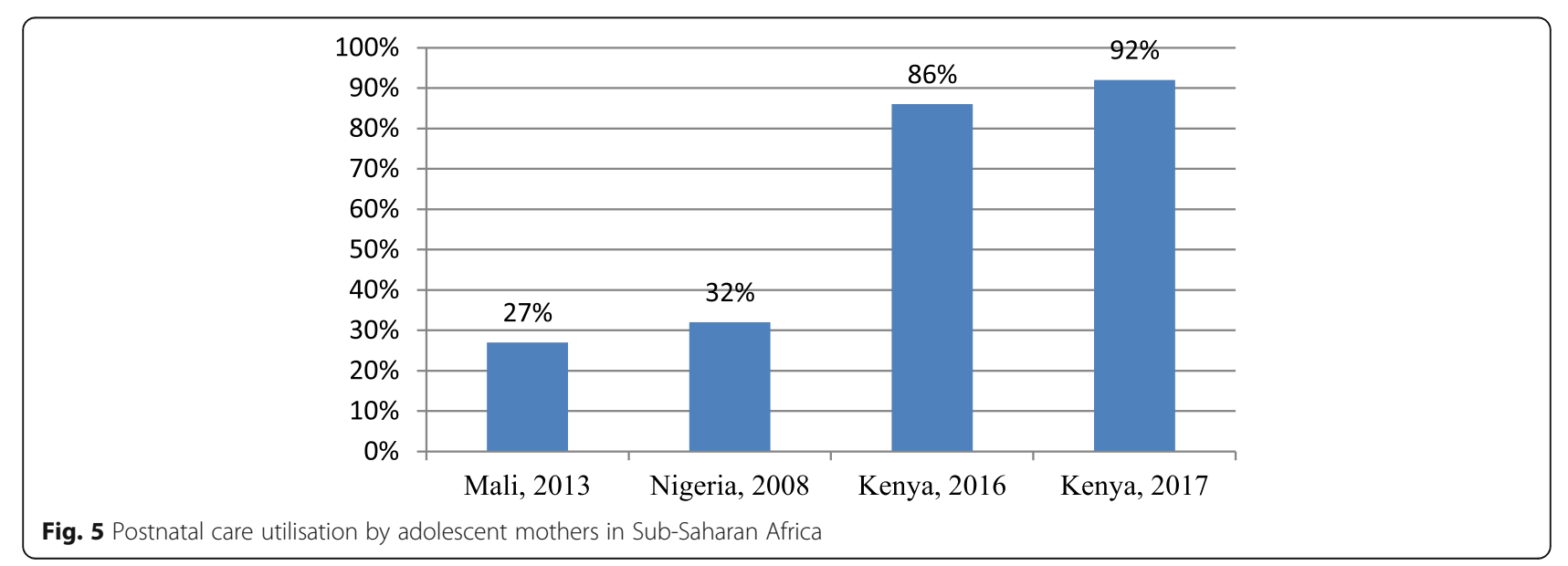




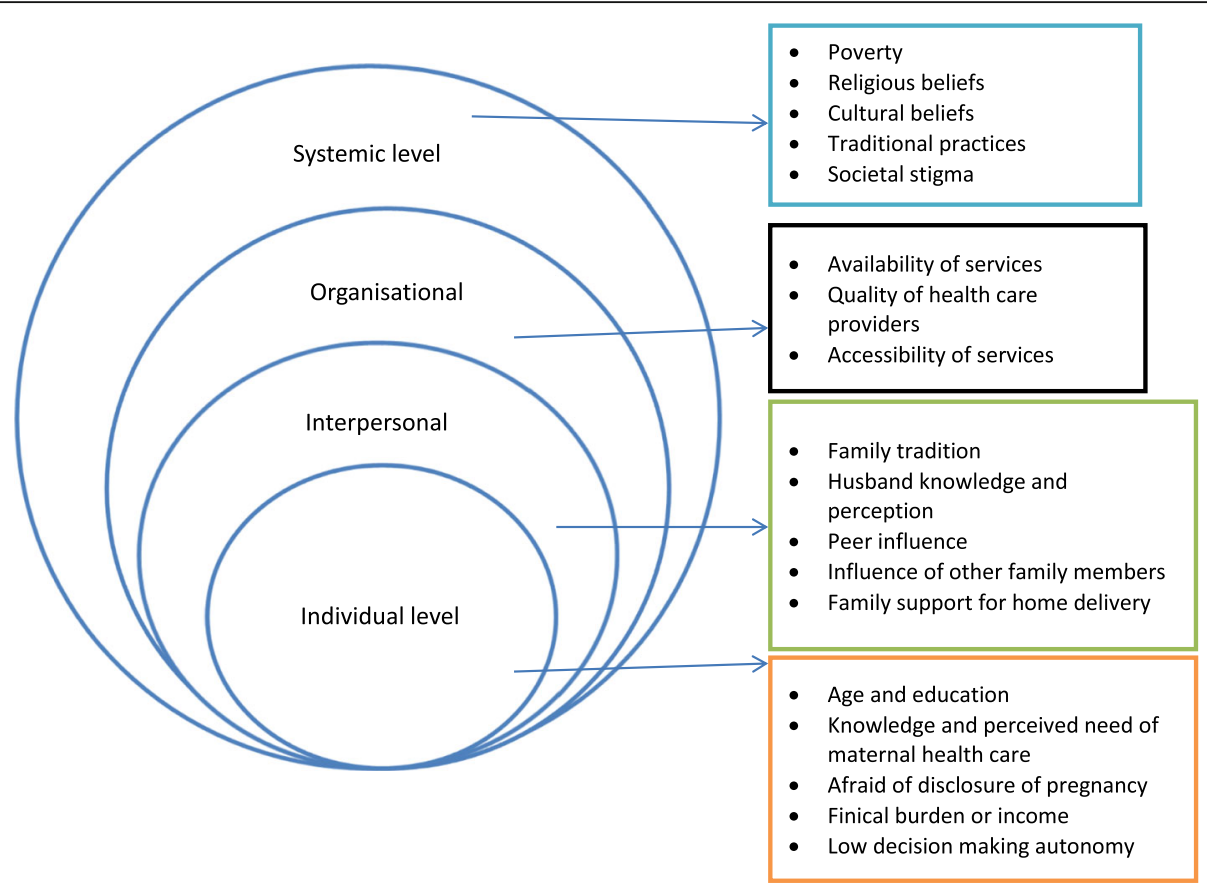

Fig. 6 A socioecological analysis of factors influencing adolescent mothers' engagement with maternity care in Sub-Saharan Africa

impact of first trimester ANC visits on skilled birth delivery utilisation other studies [16, 28, 40,42] identified the influence of frequent ANC visits were attending at least four times significantly influenced young women's utilisation of skilled birth delivery care. Conversely, one study reported that adolescent mothers in rural Malawi who attended ANC during the first, and early in the second, trimester were less likely to attend skilled birth delivery [29]. Others revealed that having at least four antenatal care (ANC) visits [42] increased utilisation of safe or skilled birth delivery care [40] and had shown a substantial effect on the use of PNC service. These findings suggest the need to integrate maternal health care service to better improve adolescent mother's utilisation of maternity care [28]. This is also important for improving child health as children whose mothers received maternity care were more likely to receive full immunization [28].

\section{Systemic level}

The included studies identified few systemic level factors that influence the utilisation of maternal health services by adolescents. For instance, the utilisation of all three maternal healthcare services was observed to increase with the increase in wealth quintile [16, 24, 25, 36, 44] where adolescent women in the middle and high wealth categories were significantly likely to use maternal health care services [16, 25, 28, 36, 44]. One study reported on the barriers to accessing ANC care by adolescent mothers which include ANC with traditional birth attendants [27] that reduced the perceived need for adolescent women to access skilled maternity care. Unmarried pregnant adolescents felt ashamed and experienced stigma in front of their peers, neighbours and even relatives and as a result was afraid to visit health facilities [41]. In addition, Islamic adolescents appeared to have a higher probability of using maternal health services compared to Catholic adolescents [40]. These findings suggest that multiple factors influence adolescent mothers' utilisation of maternal health care, and multiple and multilevel interventions that address all levels of the socioecological model are needed to improve adolescent mothers' health and wellbeing in Sub-Saharan Africa.

\section{Discussion}

Our review indicates that maternal health service utilisation in the majority of Sub-Saharan African countries is still low. The review also suggests that there is a wide discrepancy in the use of maternity care services by adolescent mothers across countries in Sub-Saharan Africa. A socioecological analysis of the data also identified several factors at individual, interpersonal, organisational and community levels that influence the use of maternity care, suggesting the need for multiple and multilevel interventions targeting this group. This is critical given that young women are at higher risk of experiencing complications during pregnancy, childbirth and the postpartum period which may lead to maternal and child mortality or a lifetime of poor health outcomes. 
Although the WHO classifies adolescent pregnancy as high risk and recommends close monitoring by skilled professionals from the beginning of the pregnancy [3] most of the studies reported that adolescent girls did not achieve the minimum four ANC visits during pregnancy and instead initiated ANC visits late in the second or third trimesters. This is attributed to inadequate knowledge on essential aspects of ANC service and misconceptions (feeling well and baby is kicking). However, one study done in Kenya reported that teenage women had good general knowledge of the common danger signs during pregnancy [48]. This can be due to improved awareness of ANC services in that specific country as shown by the high percentage of women reporting at least one ANC visit.

The socioecological analysis indicated that the majority of the studies reported that women's and their partner's education is the main factor influencing the use of ANC, delivery by skilled professionals and PNC. This is in line with the findings of previous studies in Sub-Saharan Africa and elsewhere [20]. Past research suggested that educated men and women are more likely to have knowledge about the benefits of skilled maternity care and the required empowerment to access care [20]. Effort is needed to strengthen schooling by expanding non-formal educational options for adolescent girls and encouraging adolescent girls to come back to school after they give birth. This is significant given the difficulty of re-entry of adolescent mothers into school due to traditional and institutional ideologies in Sub-Saharan African countries [51]. Clearly, effort is needed from governmental and nongovernmental organizations to change such barriers as they perpetuate cycles of disadvantage by restricting young women's access to education, future employment, financial stability and therefore empowerment - key factors that increase maternal health care access and utilisation [52]. Further, covering direct extraneous costs such as books, school uniforms, and transportation and indirect (opportunity) costs of schooling were also other ways to increase school attainment among teen mothers [53].

Economic status of the adolescent mother was also found to be positively associated with the use of maternal health care with adolescents in the wealthier group reporting better engagement with maternity care compared to the poorer ones. Muldoon and colleagues suggested that poor adolescents lack resources to spend on healthcare. Also, poor adolescents are more likely to be disengaged from social networks, thus, less likely to be reached by programs aiming to improve maternal health service utilisation of adolescent mothers [54]. Therefore, poverty reduction interventions for adolescent girls may have a more transformative power and longer-lasting impacts on their future sexual and reproductive health outcomes.
Social and cultural beliefs, and practices regarding pregnancy and childbirth have a significant influence on maternal health [55]. For example, in Sub-Saharan Africa and South Asia, religion often influences beliefs, norms and values related to the use of skilled maternal health services [56]. For instance, some women and societies may believe that birth is a test of endurance, careseeking is a sign of weakness or that health facility delivery is only for prolonged and complicated labour $[56,57]$. In addition, teenage women may be less familiar with biomedical maternity services and more exposed to traditional birth attendants especially in rural and remote areas of Sub-Saharan Africa [58] Wakefield and colleagues have also suggested the use of media to target social norms and beliefs at a community level [59]. For example, television, radio, print media can be used to disseminate consistent messages promoting the use of maternal health services and increase discussion of these issues within the community. However, previous studies have reported that many Nigerian women, particularly those in rural areas, rate the services of the traditional birth attendants (TBAs) as being of higher quality than that of medical healthcare practitioners, particularly with regards to interpersonal communications and relationships [60]. TBAs have been reported to be more considerate and to provide more compassionate care [61]. Improving health providers' competency including their ability to communicate to adolescent clients is therefore essential to increase adolescent mothers' utilisation of skilled maternity care [61].

Special efforts are needed to focus on creating awareness on the benefit of maternal health care when adolescents attend ANC. In order to do this strengthening staffing is a priority, since shortage of staff is a significant barrier to adequate service delivery [41]. Furthermore, increasing access to family planning for adolescent girls to prevent early childbearing and poor maternal health outcomes is required. Importantly, the provision of family planning education and services should be part of an integrated system between schools, communities, health organisations, and governments to ensure that young women are empowered to make decisions about their sexual and reproductive health as soon as possible instead of during the postnatal period when such counselling is provided. Also, relevant efforts are needed to involve community leaders and other key stakeholders as agents of change [62]. Such organizational change is especially needed in rural areas given the many barriers that restrict these women from accessing and therefore utilizing maternal health care $[63,64]$.

Given that adolescents girls are not always comfortable receiving ANC service together with older women, because they fear judgments and ridicule from them, 
establishing separate maternal care services for adolescent girls can increase ANC utilisation. Significant effort is also needed to increase male partner involvement in adolescent women's maternity care, delivery and followup. Again this requires a whole systems approach which first reduces the stigma of teenage pregnancy, increasing social supports around gender responsibility for offspring and engages men in ways which meet their needs for empowerment within the maternity care setting.

The review suggests that factors related to health providers such as negative attitudes and lack of training and sensitivity towards adolescent women's needs influence the use of maternal health services by adolescent mothers in Sub-Saharan Africa. These findings are in line with previous studies which reported that adolescent mothers are sensitive to health providers' attitudes and easily lose motivation to seek care $[65,66]$. This review also indicates that adolescent mothers experience communication difficulties when interacting with care providers due to lack of privacy, confidentiality, and trust with health providers. As such, health providers need to give special attention to adolescent mothers as they are more likely to have others infections such as STIs and HIV and need more explanation of maternity care and motherhood compared to older mothers [41]. HCPs also need additional training to provide care that is sensitive and responsive to adolescent mothers' needs [33].

Overall, research into the utilisation of maternal health service utilisation by adolescent women in Sub-Saharan Africa concentrates mainly on ANC with only a handful of studies addressing skilled birth delivery and PNC, which implies that additional research into adolescent women's experiences of accessing skilled birth care and PNC is needed. This is critical as maternity service utilisation is the main window of opportunity for the provision of contraceptive services to prevent the recurrence of unplanned pregnancy among this vulnerable population. In addition, only one study has addressed the health provider views and experiences of providing maternity care to adolescent mothers which again suggests the need for more research into this area of maternity care. The majority of the studies also used quantitative designs involving a small number of adolescent women. As such the representativeness of these studies is questionable given the high rate of adolescent fertility in Sub-Saharan Africa. In response to this imperative, the research team is currently examining adolescent mother's maternity service utilisation in Ethiopia using the large size, nationally representative demographic and health survey data.

\section{Limitations}

This systematic review has a number of limitations that should be highlighted. The review may have publication bias as it considered only published articles and essential data from unpublished sources might have been missed. In addition, the studies included in this review lack power and representativeness due to small sample sizes. There are also more than 20 nations in Sub-Saharan Africa where French is an official language and the review may have missed significant data as it considered only articles written in English. This implies that generalisation of the findings to Sub-Saharan Africa may not be feasible.

\section{Conclusions}

The review reveals that a significant number of adolescent women in Sub-Saharan Africa do not access and use maternity services during pregnancy. Several factors influence the maternity service utilisation patterns of adolescents which encompass individual, interpersonal, institutional, and systemic levels. This implies that interventions targeting the women, their partners, healthcare professionals and the system are necessary to improve adolescent mother's engagement with maternity care in Sub-Saharan Africa. Notably, women need to be empowered through education and employment to improve their decision making autonomy about accessing care as having higher decision making freedom is associated with more ANC visits and skilled care during delivery. Access to care should also be improved especially for adolescents in rural areas, and increasing the number of providers would help to reduce waiting times and improve access to maternity care. Maternity services should also be enhanced through training of health providers to overcome prejudices that act as a barrier to utilisation. Finally, the provision of examination rooms and waiting areas that maintain privacy for adolescent mothers is required. These are just a few changes needed while systems and societies embark on the arduous journey of improving the health and wellbeing of teenage mothers with the aim of improving socioecological outcomes for whole communities and countries.

\section{Abbreviations \\ ANC: Antenatal care; DHS: Demographic and Health Survey; EDHS: Ethiopian Demographic and Health Survey; HCP: Health Care Provider; \\ ISPOR: International Society for Pharmacoeconomics and Outcomes \\ Research; PMTCT: Prevention of mother to child transmission; PNC: Postnatal care; SRH: Sexual and Reproductive health; UN: United Nation; WHO: World Health Organization}

\section{Acknowledgments}

The authors would like to acknowledge Western Sydney University Campbelltown campus library staff for assisting with systematic literature search.

\section{Authors' contributions}

TM, TD and JP designed the study. TM and TD conducted the systematic search, article screening and quality assessment with continuous support from JP. TM, TD and JP analysed the data. TM drafted the manuscript and TD and JP read, revised and approved the final manuscript. 


\section{Funding}

This research did not receive any grant or funding.

\section{Availability of data and materials}

The datasets used and/or analysed during the current study are available from the corresponding author on reasonable request.

\section{Ethics approval and consent to participate}

Not applicable.

\section{Consent for publication}

Not applicable.

\section{Competing interests}

The authors declare that they have no competing interests.

\section{Author details}

'Translational Health Research Institute (THRI), School of Medicine, Western Sydney University, Penrith, NSW 2751, Australia. ${ }^{2}$ School of Science and Health, Western Sydney University, Penrith, NSW 2751, Australia.

Received: 13 June 2018 Accepted: 11 September 2019 Published online: 21 October 2019

\section{References}

1. WHO. Programming for adolescent health and development report of WHO/UNFPA/UNICEF study group on programming for adolescents health. Geneva: WHO; 1999

2. Morris JL, Rushwan H. Adolescent sexual and reproductive health: the global challenges. Int J Gynaecol Obstet. 2015;131(Suppl 1):S40-2.

3. World Health Organization. Adolescent pregnancy; 2014.

4. Corcoran J, Franklin C, Bennett P. Ecological factors associated with adolescent pregnancy and parenting. Soc Work Res. 2000;24(1):29-39.

5. Nove A, Matthews Z, Neal S, Camacho AV. Maternal mortality in adolescents compared with women of other ages: evidence from 144 countries. Lancet Glob Health. 2014;2(3):e155-64.

6. Kumbi S, Isehak A. Obstetric outcome of teenage pregnancy in northwestern Ethiopia. East Afr Med J. 1999;76(3):138-40.

7. Kurth F, Bélard S, Mombo-Ngoma G, Schuster K, Adegnika AA, BouyouAkotet MK, et al. Adolescence as risk factor for adverse pregnancy outcome in Central Africa-a cross-sectional study. PLoS One. 2010;5(12):e14367.

8. Mukhopadhyay P, Chaudhuri R, Paul B. Hospital-based perinatal outcomes and complications in teenage pregnancy in India. J Health Popul Nutr. 2010;28(5):494

9. Elimmam BG, Abdel-Rahman ME, Saghiron AO. Foetal and maternal pregnancy outcomes among teenage and adult mothers at Omdurman maternity hospital in Sudan. Khartoum Med J. 2014:6:2.

10. WHO. Making pregnancy safer: the critical role of the skilled attendant: a joint statement by WHO, ICM and FIGO; 2004.

11. Reynolds HW, Wong EL, Tucker H. Adolescents' use of maternal and child health services in developing countries. Int Fam Plan Perspect. 2006;32(1):6-16

12. Graham WJ, Bell JS, Bullough $\mathrm{CH}$. Can skilled attendance at delivery reduce maternal mortality in developing countries? In: Safe motherhood strategies: a review of the evidence; 2001.

13. Robinson JJ, Wharrad $\mathrm{H}$. The relationship between attendance at birth and maternal mortality rates: an exploration of United Nations' data sets including the ratios of physicians and nurses to population, GNP per capita and female literacy. J Adv Nurs. 2001;34(4):445-55.

14. Buor D, Bream K. An analysis of the determinants of maternal mortality in sub-Saharan Africa. J Women's Health (2002). 2004;13(8):926-38.

15. Magadi MA, Agwanda AO, Obare FO. A comparative analysis of the use of maternal health services between teenagers and older mothers in subSaharan Africa: evidence from demographic and health surveys (DHS). Soc Sci Med. 2007:64(6):1311-25.

16. Rai $R$, Singh $P$, Singh $L$. Utilization of maternal health care services among married adolescent women: insights from the Nigeria demographic and health survey, 2008. Womens Health Issues. 2012;22(4):e407-14.

17. Maternal mortality [http://www.who.int/mediacentre/factsheets/fs348/en/] Accessed 01 May 2018.
18. Simkhada B, ERv T, Porter M, Simkhada P. Factors affecting the utilization of antenatal care in developing countries: systematic review of the literature. J Adv Nurs. 2008;61(3):244-60.

19. Say L, Raine R. A systematic review of inequalities in the use of maternal health care in developing countries: examining the scale of the problem and the importance of context. Bull World Health Organ. 2007:85(10):812-9.

20. Shahabuddin A, Delvaux T, Abouchadi S, Sarker M, De Brouwere V. Utilization of maternal health services among adolescent women in Bangladesh: a scoping review of the literature. Trop Med Int Health. 2015;20(7):822-9.

21. Bronfenbrenner U. The ecology of human development. Cambridge: Harvard University Press; 2009.

22. Sword W. A socio-ecological approach to understanding barriers to prenatal care for women of low income. J Adv Nurs. 1999:29(5):1170-7.

23. Sallis JF, Owen N, Fisher E. Ecological models of health behavior. Health Behav Theor Res Pract. 2015:5:43-64.

24. Alemayehu T, Haidar J, Habte D. Utilization of antenatal care services among teenagers in Ethiopia: a cross sectional study. Ethiop J Heal Dev. 2010;24(3):121.

25. Ochako R, Fotso J-C, Ikamari L, Khasakhala A. Utilization of maternal health services among young women in Kenya: insights from the Kenya demographic and health survey, 2003. BMC Pregnancy Childbirth. 2011;11(1):1.

26. Singh $P$, Singh L, Kumar C, Rai R. Correlates of maternal healthcare service utilisation among adolescent women in Mali: analysis of a nationally representative cross-sectional survey, 2006. J Publ Health. 2013;21(1):15-27.

27. Chaibva CN, Roos JH, Ehlers VJ. Adolescent mothers' non-utilisation of antenatal care services in Bulawayo, Zimbabwe. Curationis. 2009;32(3):14-21.

28. Rai $R$, Singh $P$, Singh L, Kumar $C$. Individual characteristics and use of maternal and child health services by adolescent mothers in Niger. Matern Child Health J. 2014:18(3):592-603.

29. Brabin L, Verhoeff F, Kazembe P, Brabin B, Chimsuku L, Broadhead R. Improving antenatal care for pregnant adolescents in southern Malawi. Acta Obstet Gynecol Scand. 1998;77(4):402-9.

30. Gross K, Alba S, Glass T, Schellenberg J, Obrist B. Timing of antenatal care for adolescent and adult pregnant women in south-eastern Tanzania. BMC Pregnancy Childbirth. 2012;12:16.

31. Magadi M, Agwanda A, Obare F, Taffa N. Size of newborn and caesarean section deliveries among teenagers in sub-Saharan Africa: evidence from DHS. J Biosoc Sci. 2007;39(2):175-87.

32. Mngadi PT, Thembi IT, Ransjö-Arvidson AB, Ahlberg BM. Quality of maternity care for adolescent mothers in Mbabane, Swaziland. Int Nurs Rev. 2002; 49(1):38-46.

33. Rall N, James SV, Strümpher J. Pregnant teenagers' experiences of communication at antenatal clinics in South Africa. Afr J Nurs Midwife. 2013; 15(2):144-56.

34. Musarandega R, Machekano R, Chideme M, Muchuchuti C, Mushavi A, Mahomva A, et al. PMTCT service uptake among adolescents and adult women attending antenatal Care in Selected Health Facilities in Zimbabwe. J Acquir Immune Defic Syndr. 2017:75(2):148-55.

35. Ebeigbe PN, Gharoro EP. Obstetric complications, intervention rates and maternofetal outcome in teenage nullipara in Benin City, Nigeria. Trop Doct. 2007;37(2):79-83.

36. Banke-Thomas A, Banke-Thomas O, Kivuvani M, Ameh C. Maternal health services utilisation by Kenyan adolescent mothers: analysis of the demographic health survey 2014. Sex Reprod Healthc. 2017:12:37-46.

37. Adam GK, Elhassan EM, Ahmed AM, Adam I. Maternal and perinatal outcome in teenage pregnancies in Sudan. Int J Gynaecol Obstet. 2009; 105(2):170-1.

38. Ronen K, McGrath CJ, Langat AC, Kinuthia J, Omolo D, Singa B, et al. Gaps in adolescent engagement in antenatal care and prevention of mother-to-child HIV transmission services in Kenya. J Acquir Immune Defic Syndr. 2017;74(1):30-7.

39. Worku EB, Woldesenbet SA. Factors that influence teenage antenatal care utilization in John Taolo Gaetsewe (JTG) district of northern Cape Province, South Africa: underscoring the need for tackling social determinants of health. Int J MCH and AIDS. 2016;5(2):134-45.

40. Rai $R$, Singh $P$, Kumar C, Singh L. Factors associated with the utilization of maternal health care services among adolescent women in Malawi. Home Health Care Serv Q. 2013:32(2):106-25.

41. Hokororo A, Kihunrwa A, Kalluvya S, Changalucha J, Fitzgerald D, Downs J. Barriers to access reproductive health care for pregnant adolescent girls: a qualitative study in Tanzania. Acta Paediatrica. 2015;104(12):1291-7. 
42. Birungi H, Obare F, van der Kwaak A, Namwebya JH. Maternal health care utilization among HIV-positive female adolescents in Kenya. Int Perspect Sex Reprod Health. 2011;37(3):143-9.

43. Rukundo GZ, Abaasa C, Natukunda PB, Ashabahebwa BH, Allain D. Antenatal services for pregnant teenagers in Mbarara municipality, southwestern Uganda: health workers and community leaders' views. BMC Pregnancy Childbirth. 2015;15:351.

44. Banke-Thomas O, Banke-Thomas A, Ameh CA. Utilisation of maternal health services by adolescent mothers in Kenya: analysis of the demographic health survey 2008-2009. International journal of adolescent medicine and health 2016;30(2)

45. Helleringer S. Understanding the adolescent gap in HIV testing among clients of antenatal Care Services in West and Central African Countries. AIDS \& Behavior. 2017;21(9):2760-73.

46. Duggan R, Adejumo O. Adolescent clients' perceptions of maternity care in KwaZulu-Natal, South Africa. Women Birth. 2012;25(4):e62-7.

47. Mulinge $\mathrm{N}$, Bidemi $\mathrm{O}$, Aimakhu $\mathrm{C}$. Factors influencing utilization of antenatal care services among teenage mothers in Malindi Sub-County Kenya-a cross sectional study. Sci J Publ Health. 2017;5:61-7.

48. Mulinge $N$, Yusuf $\mathrm{O}$, Aimakhu C. Factors influencing utilization of antenatal care services among teenage mothers in Malindi Sub-County Kenya-a cross sectional study. Sci J Publ Health. 2017;5(2):61-7.

49. Langhaug L, Cowan F, Nyamurera T, Power R. Improving young people's access to reproductive health care in rural Zimbabwe. AIDS Care. 2003;15(2):147.

50. Mngad PT, Faxelid E, Zwane IT, Höjer B, Ransjo-Arvidson AB. Health providers' perceptions of adolescent sexual and reproductive health care in Swaziland. Int Nurs Rev. 2008:55(2):148-55.

51. Chilisa B. National policies on pregnancy in education systems in subSaharan Africa: the case of Botswana. Gend Educ. 2002;14(1):21-35.

52. Filmer D, Fox L. Youth employment in sub-Saharan Africa. Washington: World Bank Publications; 2014.

53. Fiszbein A, Schady NR. Conditional cash transfers: reducing present and future poverty. Washington: World Bank Publications; 2009.

54. Rani M, Lule E. Exploring the socioeconomic dimension of adolescent reproductive health: a multicountry analysis. Int Fam Plan Perspect. 2004; 30(3):110-7.

55. Goodburn EA, Gazi R, Chowdhury M. Beliefs and practices regarding delivery and postpartum maternal morbidity in rural Bangladesh. Studies in family planning. 1995;26(1):22-32.

56. Mrisho M, Schellenberg JA, Mushi AK, Obrist B, Mshinda H, Tanner M, et al. Factors affecting home delivery in rural Tanzania. Trop Med Int Health. 2007; 12(7):862-72.

57. Walton D, Maria L, Schbley M. Maternal healthcare in Bangladesh and gender equity: a review article. Online J Health Ethics. 2013:9(1):8.

58. Sarker BK, Rahman M, Rahman T, Hossain J, Reichenbach L, Mitra DK: Reasons for Preference of Home Delivery with Traditional Birth Attendants (TBAs) in Rural Bangladesh: A Qualitative Exploration. PloS one. 2016;11(1): e0146161-e0146161.

59. Wakefield MA, Loken B, Hornik RC. Use of mass media campaigns to change health behaviour. Lancet. 2010;376(9748):1261-71.

60. Svanemyr J, Chandra-Mouli V, Christiansen CS, Mbizvo M. Preventing child marriages: first international day of the girl child "my life, my right, end child marriage". Reprod Health. 2012;9(1):31.

61. Nair M, Baltag V, Bose K, Boschi-Pinto C, Lambrechts T, Mathai M. Improving the quality of health Care Services for Adolescents, globally: a standardsdriven approach. J Adolesc Health. 2015;57(3):288-98.

62. Stern E, Pascoe L, Shand T, Richmond S. Lessons learned from engaging men in sexual and reproductive health as clients, partners and advocates of change in the Hoima district of Uganda. Cult Health Sex. 2015;17(sup2):190-205.

63. Atuoye KN, Dixon J, Rishworth A, Galaa SZ, Boamah SA, Luginaah I. Can she make it? Transportation barriers to accessing maternal and child health care services in rural Ghana. BMC Health Serv Res. 2015;15:333.

64. Puchalski Ritchie LM, Khan S, Moore JE, Timmings C, van Lettow M, Vogel $J$, et al. Low- and middle-income countries face many common barriers to implementation of maternal health evidence products. J Clin Epidemiol. 2016;76:229-37.

65. Aaro LE, Flisher AJ, Kaaya S, Onya H, Fuglesang M, Klepp Kl, et al. Promoting sexual and reproductive health in early adolescence in South Africa and Tanzania: development of a theory- and evidence-based intervention programme. Scand J Public Health. 2006;34(2):150-8.
66. Chaibva CN, Ehlers VJ, Roos JH. Midwives' perceptions about adolescents' utilisation of public prenatal services in Bulawayo, Zimbabwe. Midwifery. 2010;26(6):e16-20

\section{Publisher's Note}

Springer Nature remains neutral with regard to jurisdictional claims in published maps and institutional affiliations.
Ready to submit your research? Choose BMC and benefit from:

- fast, convenient online submission

- thorough peer review by experienced researchers in your field

- rapid publication on acceptance

- support for research data, including large and complex data types

- gold Open Access which fosters wider collaboration and increased citations

- maximum visibility for your research: over $100 \mathrm{M}$ website views per year

At $\mathrm{BMC}$, research is always in progress.

Learn more biomedcentral.com/submissions 